\title{
Effects Of Comprehensive Income On ROE In A Context Of Crisis: Empirical Evidence For IBEX-35 Listed Companies (2004-2008)
}

Francisco Sousa Fernández, University of Cantabria, Spain María Mercedes Carro Arana, University of Cantabria, Spain

\begin{abstract}
Comprehensive income is becoming increasingly important as an indicator of corporate performance at an international level [SFAS 130 by the FASB (1997) and NIC 1 by the IASB, revised in 2007, among others]. Given this importance, this paper intends to assess its impact on the Return on Equity (ROE), as opposed to the more traditional net income, for the period 20042008 for the select group of the Spanish IBEX-35 listed companies. Moreover, working on this period will also allow us to verify the incidence of comprehensive income on the ROE within a context of economic crisis, especially for the year 2008, with a large recession and steep drops in the stock markets. For this empirical study, we took as reference the pertinent information disclosed in the Consolidated Annual Reports of these listed companies, formulated pursuant to the IFRS by the IASB, especially pursuant to IAS 1. The non-parametric Wilcoxon Signed-Rank Test was used to perform the corresponding statistic comparisons, as the variables in certain years did not conform to normalcy. The results of our paper show a statistically significant impact of the ROE calculated pursuant to comprehensive income as opposed to the ROE determined pursuant to the net income. This was evidenced for three of the five years that were studied, especially for 2008, when there was a spectacular decline in the ROE calculated pursuant to the comprehensive income as opposed to that calculated pursuant to the net income. We consider this could be a contribution to the international debate regarding the need to include other measurements of corporate performance that are broader than the traditional net income in certain ratios of the fundamental analysis. This could represent the basis for adopting financial decisions that are much more in tune with the reality of the market.
\end{abstract}

Keywords: ROE (Comprehensive Income), ROE (Net Income), SFAS 130 by the FASB, IAS 1 by the IASB, IBEX-35 Listed Companies, Context of Crisis

\section{INTRODUCTION}

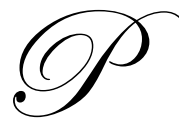

ursuant to the SFAC 6 by the FASB (1985, par. 70), comprehensive income is "The change in equity of a business enterprise during a period from transactions and other events and circumstances from non-owner sources. It includes all changes in equity during a period except those resulting from investments by owners and distributions to owners".

Comprehensive income is the traditional net income plus or minus those items of income and expense that accounting standards permit or require to be recognized in equity outside net income, which in the case of the American regulation are certain foreign currency translation adjustments, unrealized gains and losses on securities, minimum pension liability adjustment and derivatives and cash flow hedges. 
Consequently, comprehensive income is more related to the fluctuation of share prices and exchange rates than traditional net income. Thus, the purpose guiding the most influential accounting standard setters around the world when they require that companies reveal their comprehensive income is to confer greater importance to financial information for users regarding results, particularly for investors, considered in the Conceptual Framework [SFAC 1 (1978) by the FASB] as primary users. ${ }^{1}$

In the nineties, a powerful movement began which pushed for companies to disclose comprehensive income in the main body of their periodic financial statements, as is regulated in SFAS 130 (1997) by the FASB and in the IAS 1 (1997) by the IASB, revised in 2003 and 2007, among others.

Within the context of these trends in international financial information, we set out to look at an area as yet unexplored, that is the empirical study of whether the Return On Equity (ROE) calculated pursuant to the comprehensive income shows a significant impact as opposed to the same ratio calculated pursuant to the net income. ${ }^{2}$ To this end we took as reference the select group of the Spanish IBEX-35 listed companies for the years 2004-2008.

Moreover, working on this period will also allow us to verify the incidence of comprehensive income on the ROE within a context of economic crisis, especially for the year 2008, with a large recession and steep drops in the stock markets

For this empirical study, we took as reference the pertinent information disclosed in the Consolidated Annual Reports of said listed companies, formulated pursuant to the IFRS by the IASB, especially pursuant to IAS 1.

In order to perform the pertinent statistical contrasts it may be suitable to use the paired T-test for the case of two related samples. However, since the variables did not conform to normalcy in some of the years studied, we considered the alternative non-parametrical Wilcoxon Signed-Rank Test to be the most appropriate method.

The results of our paper show a statistically significant impact of the ROE calculated pursuant to comprehensive income as opposed to the ROE determined pursuant to the net income. This was evidenced for three of the five years studied, especially for 2008, when there was a spectacular decline in the ROE calculated pursuant to the comprehensive income as opposed to that calculated pursuant to the net income.

We consider this could be a contribution to the international debate regarding the need to include other measurements of corporate performance that are broader than the traditional net income in certain ratios of the fundamental analysis. This could represent the basis for adopting financial decisions that are much more in tune with the reality of the market.

\section{RESEARCH DESIGN} of our study.

In accordance with the general approach that we have referred to, we would now like to specify the design

\subsection{Aim}

When we looked at the empirical literature on comprehensive income available internationally in recent years, we saw that, apart from a series of descriptive studies [Luecke and Meeting, 1998; Bhamornsiri and Wiggins, 2001; Pandit et al., 2006; among others], a group of papers focused on the capital market [Dhaliwal et al., 1999; O'Hanlon and Pope, 1999; Hodder et al., 2006, among others]; other papers analysed the impact of comprehensive income as opposed to net income from different viewpoints [Sousa (2008), Sousa (2009), Sousa and Carro (2009a, $2009 \mathrm{~b}$ and 2009c]; and some research projects were focused on studying the impact of the presentation formats on analysts and investors [Hirst and Hopkins, 1998; Maines and McDaniel, 2000; and Hunton et al., 2006]. 
However, there are no studies that have considered the impact of comprehensive income on the ROE, specifically, within the framework of such a serious crisis as the present one. That is why, as was stated in the Introduction, we decided to study whether the ROE calculated pursuant to the comprehensive income has a significant impact as opposed to that calculated pursuant to the more traditional net income as the main object of our paper. $^{2}$

We limited our research to studying the impact of the ROE calculated pursuant to the comprehensive income as opposed to the ROE determined by the net income, as it is one of the essential ratios in the analysis of financial statements. Nevertheless, we are also aware that we could further assess its impact on other ratios that are equally important for the analysis, as well as on the inter-relations between them and their global perspective, not forgetting the analysis broken down into margins and rotations according to the renowned Du Pont formula.

Likewise, the study could be broadened by breaking down the ROE calculated pursuant to both types of income, for the shareholders of the parent company and the non-controlling interests, as they are comprised within equity pursuant to NIC 27 (2009). However this surpasses the object and the limits of our paper and may be studied in further research.

In any case, pursuant to the FASB's definition of comprehensive income referred to in the Introduction, we have an accounting profit or loss clearly oriented to ownership. This justifies the object and the interest of our research being limited to the consolidated ROE, as we are thus able to assess the impact of comprehensive income as opposed to net income in corporate financing attributable to the capital-risk suppliers, considered in the Conceptual Framework as primary users.

We also consider that our research may be a contribution to the international debate on the presentation of corporate performance, set forth in the EFRAG-ICAC (2006) document, Cauwenberge and Beelde (2007), and the joint project on financial statement presentation by the IASB (2009) and the FASB (2009), among others.

\subsection{Sample}

We took as reference for our research the information disclosed in the Consolidated Annual Reports of the IBEX-35 listed companies pursuant to the IFRS by the IASB, for the years 2004-2008, available on the website of the Spanish Stock Exchange Commission (CNMV) and on the websites of the listed companies.

Given that this period comprised years of economic and stock exchange expansion as well as a year of great recession and drop of the Stock Markets around the world, namely 2008, this will allow us to confirm the extent to which comprehensive income affects ROE under very unfavorable economic and financial circumstances.

We have also limited our research to the companies listed on the IBEX-35 drawn up by Bolsas y Mercados Españoles (BME), which is a capitalization-weighted stock market index, comprised of the 35 most liquid Spanish stocks traded in the continuous market, and is the benchmark index for the Bolsa de Madrid (the Madrid Stock Exchange).

Among other listed companies, the following are comprised in this index: Telefonica, Banco Santander Central Hispano, Banco Bilbao Vizcaya Argentaria, Repsol, and Endesa; these are large Spanish corporations that are present worldwide, especially in Latin America.

From January $1^{\text {st }} 2005$ all the listed companies in the European Union have the obligation to formulate their consolidated financial statements pursuant to the IFRS by the IASB. This, in addition to the current convergence of the accounting models with the IASB regulations not only at a European level, but worldwide, makes our research current and of international interest, since we work with a sampling of the most liquid 35 Spanish listed companies, applying these regulations. 


\subsection{Testing Method}

In accordance with the object that we have set, we wish to evaluate the impact of the ROE calculated pursuant to the comprehensive income as opposed to the ROE calculated pursuant to the net income, and to this purpose we first construct the variables that will be the basis for our research.

Thus, the consolidated ROE calculated pursuant to the comprehensive income for each corporate group $i$ in each year $k$ is determined by the following mathematical expression: ROE-CI $I_{i, k}=\left(\mathrm{CI}_{i, k} / \mathrm{SE}_{i, k}\right) \cdot 100$, where CI $i, k$ is the consolidated comprehensive income for each corporate group $i$ in each year $k$, and $\mathrm{SE}_{i, k}$ represents the consolidated shareholders equity of each group $i$ at the end of each year $k$, which for none of the 35 corporate groups included in the sampling registered a negative value in the period 2004-2008.

Likewise, we obtain the consolidated ROE calculated pursuant to the net income for corporate group $i$ in each year $k$, with the mathematical formula: ROE-NI $i, k=\left(\mathrm{NI}_{i, k} / \mathrm{SE}_{i, k}\right) \cdot 100$, where $\mathrm{NI}_{i, k}$ is the consolidated net income for each group $i$ in each year $k$, and $\mathrm{SE}_{i, k}$ has already been established.

The Consolidated Annual Reports of the corporate groups showed no information on the initial value of shareholders equity pursuant to the IFRS of the IASB for 2004, as the first year of obligatory application of said standards for formulation of the consolidated financial statements in the European Union was 2005, which means there is only comparative information for 2004 and not for previous years. This implied that we could not use the average values of shareholders equity for that year. Therefore we will perform all the comparisons with values taken at the closure of the financial year, instead of the average values, in order to include as many years as possible in our research.

However, when presenting and commenting on the results, we will state whether the fact of considering closure values or average values has any bearing on the results of the research.

As stated, in order to perform the contrasts, comparisons of averages between the consolidated ROE-CI and the consolidated ROE-NI with the paired T-test for the case of two related samples may have been suitable.

But as shown in Table 1, in accordance with the One-Sample Kolmogorov-Smirnov Test, we rejected the null hypothesis of normalcy for the variables made up of the differentials between the ROE-CI and the ROE-NI in the years 2004, 2005, and 2008.

Consequently, as the variables did not conform to a normal distribution in some of the years of the study, we must use the alternative non-parametric Wilcoxon Signed-Rank Test for the comparison, with a 95\% confidence level, which leads us to a $p<0.05$ significance.

This non-parametric test contrasts the null hypothesis that the averages of two related variables are the same, which applied to our specific field of research will allow us to evidence whether the consolidated ROE-CI differs significantly from the consolidated ROE-NI, both determined pursuant to the IASB regulations, for the group of the 35 IBEX listed companies in each year from 2004 to 2008. 
Table 1: One-Sample Kolmogorov-Smirnov Test

Contrast of the Normalcy of the Variables formed by the Differential between ROE-CI and ROE-NI for the Period 20042008 for the IBEX-35 Listed Companies

\begin{tabular}{|c|c|c|c|c|c|c|}
\hline & & $\begin{array}{c}\text { ROE-CI-2004 } \\
\text {-ROE-NI-2004 }\end{array}$ & \begin{tabular}{|c|} 
ROE-CI-2005 \\
-ROE-NI-2005 \\
\end{tabular} & \begin{tabular}{|c|} 
ROE-CI-2006 \\
-ROE-NI-2006 \\
\end{tabular} & \begin{tabular}{|c|} 
ROE-CI-2007 \\
-ROE-NI-2007
\end{tabular} & \begin{tabular}{|c|} 
ROE-CI-2008 \\
-ROE-NI-2008 \\
\end{tabular} \\
\hline & $\mathbf{N}$ & 35 & 35 & 35 & 35 & 35 \\
\hline Normal & Mean & -0.97 & 4.27 & -1.30 & -1.50 & -20.37 \\
\hline parameters $^{\text {a }}$ & Standard Deviation & 7.14 & 10.49 & 4.86 & 5.69 & 45.96 \\
\hline Most & Absolute & 0.254 & 0.279 & 0.155 & 0.192 & 0.347 \\
\hline Extreme & Positive & 0.180 & 0.279 & 0.126 & 0.146 & 0.305 \\
\hline Differences & Negative & -0.254 & -0.214 & -0.155 & -0.192 & -0.347 \\
\hline Kolmog & ov-Smirnov Z & 1.500 & 1.652 & 0.918 & 1.133 & 2.055 \\
\hline Asymp & Sig. (2-tailed) & 0.022 & 0.009 & 0.368 & 0.153 & 0.000 \\
\hline
\end{tabular}

a Test distribution is Normal

Source: authors' calculations, based on the Database and SPSS v.17

As we know, in many areas of human knowledge the paired T-test is used for two related samples is used, or its alternative in non-parametric tools, the Wilcoxon Signed-Rank Test, which we used in our research to contrast whether there are significant differences between two measurements taken for each of the subjects comprised in our sample, one before introducing a certain treatment or stimulus and the other one after doing so.

We decided to compare the consolidated ROE-NI with the consolidated ROE-CI, which will allow us to assess whether the aggregate of the items comprised in the comprehensive income — which are specified in the revenues and expenses that are to be initially recognized in equity - significantly affect the ROE of the corporate groups.

\section{RESEARCH RESULTS}

Table 2 shows the descriptive statistics of the variables that our research is based on, and Graphic 1 shows their profile of means throughout the study period.

Table 2: Descriptive Statistics for ROE-CI and ROE-NI in the Period 2004-2008 for IBEX-35 Listed Companies

\begin{tabular}{|c|c|c|c|c|c|c|c|c|}
\hline Variable & $\mathbf{N}$ & Mean & $\begin{array}{l}\text { Standard } \\
\text { Deviation }\end{array}$ & Minimum & $\begin{array}{c}\text { First } \\
\text { Quartile }\end{array}$ & Median & $\begin{array}{c}\text { Third } \\
\text { Quartile }\end{array}$ & Maximum \\
\hline ROE-NI-2004 & 35 & 15.86 & 7.80 & -3.19 & 12.00 & 14.60 & 19.25 & 42.32 \\
\hline ROE-CI-2004 & 35 & 14.89 & 6.82 & -5.09 & 12.23 & 14.67 & 18.26 & 30.13 \\
\hline ROE-NI-2005 & 35 & 19.75 & 10.05 & -0.06 & 13.42 & 16.96 & 24.01 & 50.93 \\
\hline ROE-CI-2005 & 35 & 24.02 & 17.08 & -3.00 & 15.82 & 19.31 & 25.81 & 104.38 \\
\hline ROE-NI-2006 & 35 & 22.51 & 10.29 & 3.28 & 16.00 & 20.71 & 29.27 & 52.58 \\
\hline ROE-CI-2006 & 35 & 21.21 & 12.27 & 3.39 & 12.53 & 19.38 & 30.00 & 56.84 \\
\hline ROE-NI-2007 & 35 & 20.21 & 11.08 & 0.16 & 16.31 & 17.71 & 21.66 & 56.81 \\
\hline ROE-CI-2007 & 35 & 18.71 & 13.68 & -14.22 & 13.01 & 17.50 & 21.89 & 61.29 \\
\hline ROE-NI-2008 & 35 & 19.75 & 21.55 & -44.69 & 12.39 & 17.44 & 26.42 & 87.15 \\
\hline ROE-CI-2008 & 35 & -0.06 & 44.56 & -154.34 & -2.87 & 8.90 & 20.62 & 52.17 \\
\hline
\end{tabular}

Source: authors' calculations, based on the database and SPSS v.17.0. 
Graphic 1: Profile of Means of ROE-CI and ROE-NI in the Period 2004-2008 for IBEX-35 Listed Companies

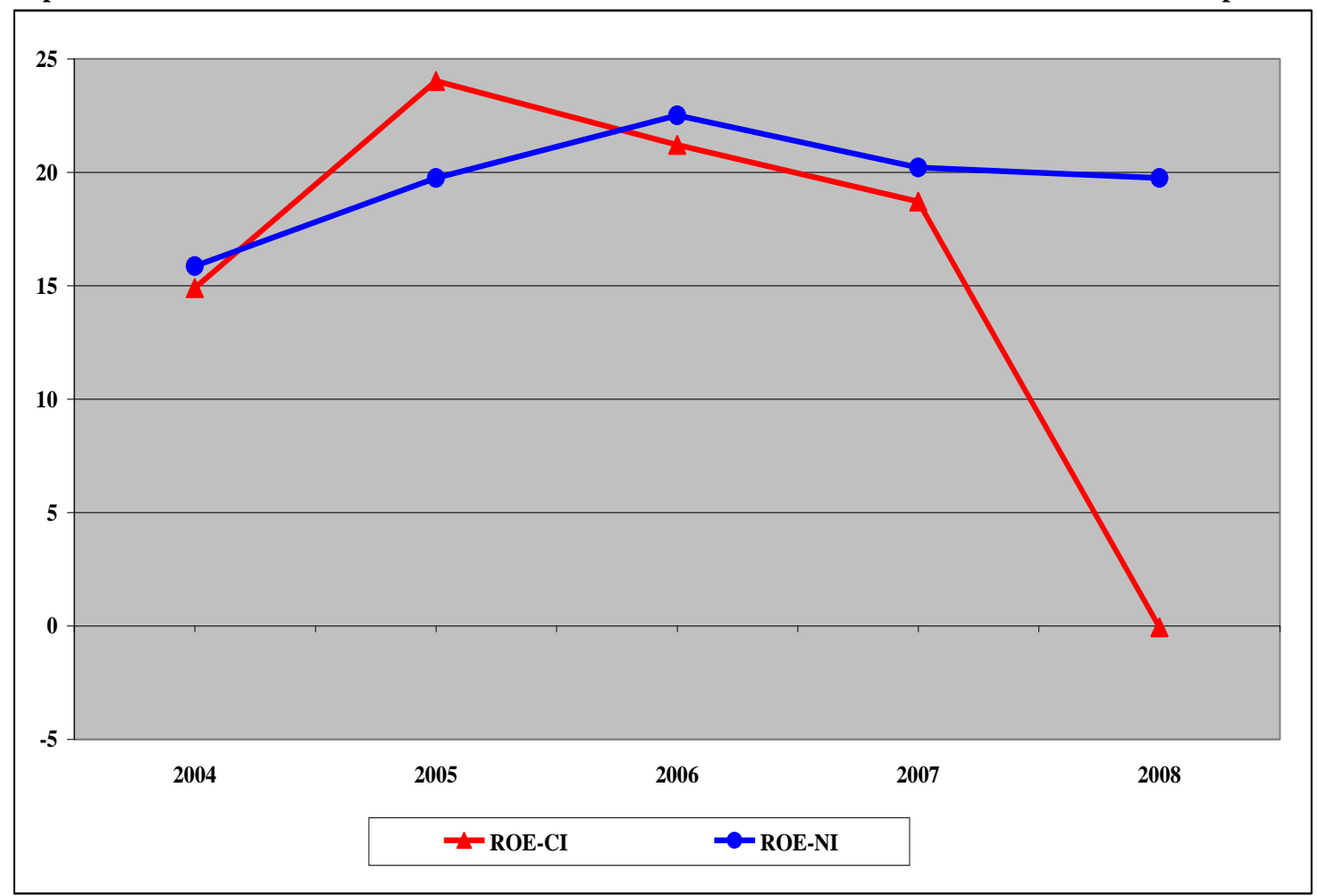

Source: authors' calculations, based on the database and Microsoft Excel 2003.

We see that for the years 2004, 2006, and 2007 the ROE-NI exceeds the ROE-CI for the aggregate of the 35 companies. However, for 2005 the ROE-CI noticeably exceeds the ROE-NI, and for 2008 it registers a spectacular drop.

Therefore, for the years of economic and stock market expansion, that is from 2004 until practically 2007 , the ROE-NI is higher than the ROE-CI in some years, and in other years it is the other way around. But where we truly see a difference that we could classify as spectacular is in 2008 , when on average the ROE calculated pursuant to the net income is very close to $20 \%$ whereas the ROE calculated pursuant to the comprehensive income is slightly in the negative area.

It is also noticeable that the ROE calculated pursuant to the net income was on average practically immune to the current serious economic and financial crisis. However, as we have seen, the crisis affects the ROE calculated pursuant to the comprehensive income in a very negative way.

Thus, taking the average values for all the corporate groups throughout the 5 year span of the study, we find the ROE based on the net income is $19.62 \%$, whereas the ROE based on the comprehensive income is $15.75 \%$. This means a decrease of the ROE by $3.87 \%$ essentially due to the current serious economic and financial crisis, as mentioned.

On the other hand, with the help of the boxplot analysis and as shown in Table 3, we wanted to identify the specific impact on the corporate groups by considering the extreme scores and outliers that are registered for each of the years studied regarding the differential between the ROE-CI and the ROE-NI. 
The extreme scores, which appear in Table 3 marked with an asterisk $(*)$, are defined as scores that are greater than 3 box lengths away from the upper or lower edge of the box. The outliers, which are noted with a circle $(\circ)$, are defined as scores that are between 1.5 and 3 box lengths away from the upper or lower edge of the box.

We can see that a significant number of corporate groups, over $30 \%$ of the sampling, show extreme scores and/or outliers for at least one year of the five-year span, with many negative values registered, some of them quite noticeable. This along general lines denotes the evident negative impact of comprehensive income on the ROE, particularly for a year of such serious economic crisis as was 2008.

Table 3: Extreme Scores (*) and Outliers ( $\circ$ ) for the IBEX-35 Listed Companies Regarding the Differential between ROE-CI and ROE-NI for the Period 2004-2008

\begin{tabular}{|c|c|c|c|c|c|c|}
\hline \multirow{2}{*}{ LISTED COMPANIES } & \multicolumn{5}{|c|}{ YEARS OF THE PERIOD 2004-2008 } & \multirow{2}{*}{$\begin{array}{c}\text { Mean } \\
\text { 2004-2008 }\end{array}$} \\
\hline & 2004 & 2005 & 2006 & 2007 & 2008 & \\
\hline Abengoa & -0.05 & 0.08 & $-0.17 *$ & $0.16 *$ & $-0.44 \circ$ & -0.08 \\
\hline Acerinox & -0.02 & 0.07 & $-0.08 \circ$ & $-0.13 \circ$ & -0.02 & -0.04 \\
\hline Actividades de Construcción y Servicios & -0.02 & 0.04 & -0.03 & $0.08 \circ$ & -0.18 & -0.02 \\
\hline Cintra & -0.02 & -0.03 & -0.02 & $-0.14 \circ$ & $-1.34 *$ & -0.31 \\
\hline Criteria Caixacorp & $0.07 \circ$ & 0.06 & -0.02 & 0.04 & $-2.41 *$ & -0.45 \\
\hline Ferrovial & 0.00 & -0.02 & 0.02 & -0.07 & $-0.54 \circ$ & -0.12 \\
\hline Grifols & -0.05 & $0.59 *$ & -0.07 & $-0.16 *$ & 0.03 & 0.07 \\
\hline Obrascón Huarte Laín & -0.03 & -0.06 & $-0.10 \circ$ & -0.04 & $-0.47 \circ$ & -0.14 \\
\hline Sacyr Vallehermoso & $0.11 \circ$ & -0.03 & -0.05 & -0.04 & -0.11 & -0.02 \\
\hline Técnicas Reunidas & -0.03 & -0.08 & $0.13 *$ & -0.03 & -0.12 & -0.03 \\
\hline Telecinco & $-0.38 *$ & 0.00 & 0.00 & 0.04 & 0.00 & -0.07 \\
\hline
\end{tabular}

Source: authors' calculations; based on the database and SPSS v. 17.

Once the descriptive statistics have been analyzed, we now proceed to perform the contrasts that will allow us to determine whether there are statistically significant differences between the ROE calculated pursuant to comprehensive income and the ROE calculated pursuant to net income.

Thus, Table 4 shows the averages and the sums of ranks pursuant to the Wilcoxon Signed-Rank Test. Important differences can be found between the sums and averages of the positive and negative ranks, which in principle denote a different conduct between the ROE-CI and the ROE-NI over the studied period.

Furthermore, when performing the contrasts, statistically significant differences are evidenced between both ranks for the years 2005, 2007, and 2008 as $p<0.05$, specifically for 2008, with $p=0.00$, as is shown in Table 5 . $^{3}$ 
Given this empirical evidence, we can state that the ROE calculated pursuant to the comprehensive income as opposed to the ROE calculated pursuant to the net income has a significant impact in three of the five years that were studied, and especially in 2008, when there was a serious economic crisis and drop in the Stock Markets.

The new elements comprised in the comprehensive income — which are basically the unrealized gains and losses in available-for-sale securities, the adjustments associated to the derivatives and cash flow hedges, and certain foreign currency translation adjustments - are now taken into consideration, which sets a much broader perspective that is closer to the reality of the markets than the perspective of traditional net income.

Therefore, a measurement of the shareholders equity performance such as the ROE shows the market impact much more clearly, as happened with the current crisis, if an inclusive-concept of income is used as opposed to the more traditional measure of the net income, providing better information for users and particularly for investors, who are considered as reference users.

Table 4: Ranks of Wilcoxon Signed-Rank Test for Comparison of ROE-NI and ROE-CI for IBEX-35 Listed Companies in the Period 2004-2008

\begin{tabular}{|c|c|c|c|c|}
\hline & & $\mathbf{N}$ & Mean Ranks & Sum of Ranks \\
\hline \multirow{4}{*}{$\begin{array}{l}\text { ROE-NI-2004 } \\
\text { ROE-CI-2004 }\end{array}$} & Negative Ranks & $13^{a}$ & 19.46 & 253.00 \\
\hline & Positive Ranks & $21^{b}$ & 16.29 & 342.00 \\
\hline & Ties & $1^{\mathrm{c}}$ & & \\
\hline & Total & 35 & & \\
\hline \multirow{4}{*}{$\begin{array}{l}\text { ROE-NI-2005 } \\
\text { ROE-CI-2005 }\end{array}$} & Negative Ranks & $25^{d}$ & 18.44 & 461.00 \\
\hline & Positive Ranks & $8^{e}$ & 12.50 & 100.00 \\
\hline & Ties & $2^{f}$ & & \\
\hline & Total & 35 & & \\
\hline \multirow{4}{*}{$\begin{array}{l}\text { ROE-NI-2006 } \\
\text { ROE-CI-2006 }\end{array}$} & Negative Ranks & 18 & 12.50 & 225.00 \\
\hline & Positive Ranks & 16 & 23.13 & 370.00 \\
\hline & Ties & 1 & & \\
\hline & Total & 35 & & \\
\hline \multirow{4}{*}{$\begin{array}{l}\text { ROE-NI-2007 } \\
\text { ROE-CI-2007 }\end{array}$} & Positive Ranks & $10^{\mathrm{j}}$ & 18.20 & 182.00 \\
\hline & Negative Ranks & $24^{k}$ & 17.21 & 413.00 \\
\hline & Ties & $1^{1}$ & & \\
\hline & Total & 35 & & \\
\hline \multirow{4}{*}{$\begin{array}{l}\text { ROE-NI-2008 } \\
\text { ROE-CI-2008 }\end{array}$} & Positive Ranks & 8 & 7.50 & 60.00 \\
\hline & Negative Ranks & 26 & 20.58 & 535.00 \\
\hline & Ties & 1 & & \\
\hline & Total & 35 & & \\
\hline
\end{tabular}

a. ROE-NI-2004 < ROE-CI-2004; b. ROE-NI-2004 > ROE-CI-2004; c. ROE-NI-2004 = ROE-CI-2004;

d. ROE-NI-2005 < ROE-CI-2005; e. ROE-NI-2005 > ROE-CI-2005; f. ROE-NI-2005 = ROE-CI-2005;

g. ROE-NI-2006 < ROE-CI-2006; h. ROE-NI-2006 > ROE-CI-2006; i. ROE-NI-2006 = ROE-CI-2006;

j. ROE-NI-2007 < ROE-CI-2007; k. ROE-NI-2007 > ROE-CI-2007; 1. ROE-NI-2007 = ROE-CI-2007;

m. ROE-NI-2008 < ROE-CI-2008; n. ROE-NI-2008 > ROE-CI-2008; o. ROE-NI-2008 = ROE-CI-2008.

Source: authors' calculations; based on the database and SPSS v. 17.

Table 5: Contrast Statistics for the Wilcoxon Signed-Rank Test for Comparison of ROE-NI and ROE-CI for IBEX-35 Listed Companies in the period 2004-2008

\begin{tabular}{|c|c|c|c|c|c|}
\hline & $\begin{array}{c}\text { ROE-NI-2004 } \\
\text { ROE-CI-2004 }\end{array}$ & $\begin{array}{c}\text { ROE-NI-2005 } \\
\text { ROE-CI-2005 }\end{array}$ & $\begin{array}{c}\text { ROE-NI-2006 } \\
\text { ROE-CI-2006 }\end{array}$ & $\begin{array}{l}\text { ROE-NI-2007 } \\
\text { ROE-CI-2007 }\end{array}$ & $\begin{array}{l}\text { ROE-NI-2008 } \\
\text { ROE-CI-2008 }\end{array}$ \\
\hline $\mathbf{Z}$ & $-0.761^{\mathrm{a}}$ & $-3.225^{\mathrm{b}}$ & $-1.239^{\mathrm{a}}$ & $-1.975^{\mathrm{a}}$ & $-4.060^{\mathrm{a}}$ \\
\hline $\begin{array}{c}\text { Asymp. Sig. } \\
\text { (2-tailed) }\end{array}$ & 0.447 & 0.001 & 0.215 & 0.048 & 0.000 \\
\hline
\end{tabular}

a. Based on negative ranks;

b. b. Based on positive ranks.

Source: authors' calculations, based on the database and SPSS v. 17. 


\section{CONCLUSIONS}

Comprehensive income is becoming increasingly important as an indicator of corporate performance, especially with the revision of the IAS 1 by the IASB in 2007. Thus, we are witness to a configuration of the corporations' profits that is much more in tune with the market reality than other measurements of profit such as the traditional net income.

Within the context of these trends in international financial information, we have empirically studied the impact of ROE calculated pursuant to the comprehensive income as opposed to the ROE calculated pursuant to the net income, using as reference the corresponding consolidated information of the select group of Spanish IBEX-35 listed companies for the period 2004-2008.

When performing the contrasts with the Wilcoxon Signed-Rank Test, statistically significant differences are found between both ratios for the years 2005, 2007 and 2008 as $p<0.05$, and specifically for 2008, with $p=$ 0.00 .

Given this empirical evidence, we can state that the ROE calculated pursuant to the comprehensive income as opposed to the ROE calculated pursuant to the net income has a significant impact in three of the five years that were studied, and especially in 2008, when there was a serious economic crisis and drop in the Stock Markets.

Therefore, a measurement of the shareholders equity performance such as the ROE shows the market impact much more clearly, as happened with the serious current crisis, if an inclusive-concept of income is used as opposed to the more traditional measure of the net income, providing better information for users and particularly for investors, who are considered as reference users in the Anglo-Saxon accounting models, and towards which the accounting models of the rest of the world are leaning.

To conclude, the empirical evidence provided in our research may entail another element to add to the debate that currently exists on international accounting literature and regulations [EFRAG-ICAC (2006), Cauwenberge and Beelde (2007), IASB (2009) and FASB (2009), among others], regarding the need for other alternative measurements of corporate performance, such as comprehensive income, which is far from the historical cost accounting model and represents a reference that is much more in tune with the market reality than the traditional net income.

\section{AUTHOR INFORMATION}

F. Sousa Fernández. PhD. Associate Professor of Financial Economy and Accounting at the University of Cantabria (Spain). Doctoral Thesis: Comprehensive Income in the Context of International Financial Information: Conceptual Framework, Comparative Analysis on Standards and an Empirical Research for European Groups Listed in NYSE and NASDAQ. He has published numerous articles in scientific and professional Journals of Accounting and Business Administration. He has won several awards for articles derived from international research in Comprehensive Income, granted by the most prestigious Associations and Organizations in the field of Accounting and Business Administration in Spain, such as AECA, ICAC, ASEPUC and CEF.

M. ${ }^{a}$ M. Carro Arana. PhD. Assistant Professor and Vice Dean in Business Administration at the University of Cantabria (Spain). She is also Legal Practicing Auditor. Doctoral Thesis: The Auditor in the Insolvency Procedures (Conceptual Framework and Empirical Research). She is Author of Different Articles in Professionals Reviews, and Papers in National Congresses (AECA, ASEPUC, ICAC) and International: European Accounting Association EAA-, Iberian-American of Finances and Systems of Information -FSI-, Assian-Pacific Conference on International Accounting Issues -APA-. She has directed research for MBA and other investigation projects on topics related with Audit, Accounting and Insolvency Procedures. 


\section{REFERENCES}

1. Beale, B. and Davey, H., The Nature and Origins of Comprehensive Income, in S. B. Dahiya (ed.), The Current State of Business Disciplines, SpellBound Publications Ltd., New Delhi, Vol. 1, pp. 81-100, 2000.

2. Bhamornsiri, S. and Wiggins, C., Comprehensive Income Disclosures, The CPA Journal, October, pp. 5456, 2001.

3. Bolsa de Madrid, IBEX-35 Listed Companies, available in http://www.bolsademadrid.es [accessed in June, 2009].

4. Brief, R. P. and Peasnell, K. V., Clean Surplus: A link Between Accounting and Finance, Garland Publishing, Inc., New York and London, 1996.

5. Cauwenberge, P. Beelde, I., On the IASB Comprehensive Income Project: An Analysis of the Case for Dual Income Display, Abacus, Vol. 43, No. 1, 2007.

6. Comisión Nacional del Mercado de Valores, CNMV, Consolidated Financial Statements of Spanish Companies listed on IBEX-35, available at http://www.cnmv.es [accessed in July and August, 2009].

7. Dhaliwal, D.; Subramanyam, K. R., and Trezevant, R., Is Comprehensive Income superior to Net Income as a measure of firm performance, Journal of Accounting and Economics, Vol. 26, pp. 43-67, 1999.

8. Feltham, G. A. and Ohlson, J. A., Valuation and Clean Surplus Accounting for Operating and Financial Activities, Contemporary Accounting Research, Vol. 12, Spring, pp. 689-731, 1995.

9. Financial Accounting Standards Board, FASB, SFAC 1, Objectives of Financial Reporting by Business Enterprises, available at http:///www.fasb.org [accessed on August 12, 2009].

10. Financial Accounting Standards Board, FASB, SFAC 6, Elements of Financial Statements (a replacement of FASB Concepts Statements 3 -incorporating an amendment of FASB Concepts Statement No.2-), 1985, available at http:///www.fasb.org [accessed on August 12, 2009].

11. Financial Accounting Standards Board, FASB, SFAS 130, Reporting Comprehensive Income, 1997, available at http:///www.fasb.org [accessed on August 12, 2009].

12. Financial Accounting Standards Board, FASB, Financial Statement Presentation, Joint Project of the IASB and the FASB, Memorandum of Understanding -MoU-, 2009, available at http://www.fasb.org [accessed in August, 2009].

13. Hirst, D. E., and Hopkins, P. E., Comprehensive Income Reporting and Analysts' Valuation Judgements, Journal of Accounting Research, Vol. 36, Supplement, pp. 47- 75, 1998.

14. Hodder, L. D.; Hopkins, P. E., and Wahlen, J. M., Risk-Relevance of Fair-Value Income Measures for Commercial Banks, The Accounting Review, Vol. 81, nº 2, pp. 337-375, 2006.

15. Hunton, J. E.; Libby, R., and Mazza, C. L., Financial Reporting Transparency and Earnings Management, The Accounting Review, Vol. 81, no 1, pp. 135-157, 2006.

16. International Accounting Standards Board, IASB, IAS 1, Presentation of Financial Statements, in International Financial Reporting Standards: Bond Volume, 2008, IASB-IASC, London, 2007.

17. International Accounting Standards Board, IASB, IAS 27, Consolidated and Separate Financial Statements, IASB, London, 2008.

18. International Accounting Standards Board, IASB, Financial Statement Presentation, Joint Project of the IASB and the FASB, Memorandum of Understanding -MoU-, 2009, available at http://www.iasb.org [accessed in August, 2009].

19. Linsmeier, T.J.; Gribble, J.; Jennings, R.G.; Lang, M.H.; Penman, S.H.; Petroni, K.R.; Shores, D.; Smith, J.H. and Warfield, T.D., An Issues Paper on Comprehensive Income, American Accounting Association's Financial Accounting Standards Committee, Accounting Horizons, Vol.11, nº 2, p. 120-126, 1997.

20. Luecke, W. and Meeting, D. T, How Companies Report Income, Journal of Accountancy, May, pp. 45-52, 1998.

21. Maines, L. A. and McDaniel, L. S, Effects of Comprehensive-Income Characteristics on Nonprofessional Investors' Judgements: The Role of Financial-Statement Presentation Format, The Accounting Review, Vol. 75, No. 2, pp. 179-207, 2000.

22. Mattessich, R., The Theory of Clean Surplus and Its Evolution: Survey and Recent Perspectives, EnergeiaRevista Internacional de Filosofía y Epistemología de las Ciencias Económicas, Vol. 1, nº 2, Universidad de Ciencias Empresariales y Sociales, Buenos Aires, invited paper (with Spanish text translation on pp. 4979), pp. 9-79, 2002. 
23. O'Hanlon, J. F. and Pope, P. F., The Value-Relevance of UK Dirty Surplus Accounting Flows, British Accounting Review, Vol. 31, pp. 459-482, 1999.

24. Pandit, G. M.; Rubenfield, A. and Phillips, J. J., Current NASDAQ Corporation Methods of Reporting Comprehensive Income, Mid-American Journal of Business, Spring, Vol. 21, nº 1. pp. 13-19, 2006.

25. Sousa Fernández, F., Comprehensive Income in the Context of International Financial Information: Conceptual Framework, Comparative Analysis on Standards and an Empirical Research for European Groups Listed in NYSE and NASDAQ [on line], Doctoral Thesis, University of Cantabria (Spain), Department of Business Administration, 2007, http://www.tesisenred.net/TDR-0430108-085640, [accessed in August, 2009].

26. Sousa Fernández, F., Evaluación Empírica del Impacto del Resultado Global frente al Resultado Neto en la Rentabilidad Financiera Consolidada de las Cotizadas Españolas en la Bolsa de Madrid, Accésit del XI Premio para Trabajos Cortos de Investigación en Contabilidad "Carlos Cubillo Valverde", convocado por ASEPUC en colaboración con el ICAC, 2008, inédito.

27. Sousa Fernández, F., Impacto del Comprehensive Income Frente al Net Income en los Grupos Empresariales Españoles Cotizados en la Bolsa de Madrid, Revista de Contabilidad y Tributación del Centro de Estudios Financieros (CEF), Núm. 309, pp. 165-214, 2009.

28. Sousa Fernández, F., Strong Impact Of Comprehensive Income On European Groups Listed In American Markets, International Business And Economics Research Journal, Vol. 8, No. 3, pp. 131-139, 2009

29. Sousa Fernández, F. and Carro Arana, Ma . M. (2009a), Impacto del Comprehensive Income frente al Net Income en la Estabilidad del Beneficio del BSCH y BBVA según US GAAP (1998-2007), Universia Business Review, No. 21, pp. 118-133, 2009.

30. Sousa Fernández, F. and Carro Arana, Ma . M. (2009b), Empirical Evaluation of the Overall Impact and by Industries of Comprehensive Income on European Groups Listed on NYSE and NASDAQ, International Business And Economics Research Journal, Vol. 8, No. 4, pp. 91-112, 2009.

31. Sousa Fernández, F. and Carro Arana, Ma. M. (2009c), Empirical Analysis of the Impact of Comprehensive Income on Basic Earnings Per Share for Spanish Companies Listed on Madrid Stock Exchange, International Business And Economics Research Journal, Vol. 8, No. 6, pp. 7-23, 2009.

32. Statistical Package for the Social Sciences, SPSS Inc., SPSS Software, v. 17.0, 2009.

\section{ENDNOTES}

1 In order to delve into further detail on the conceptual background of comprehensive income, or on an equivalent approach provided by clean surplus, the following, among others, may be consulted: Feltham and Ohlson (1995), Brief and Peasnell (1996), Linsmeier et al., AAA (1997), Beale and Davey (2000), Mattessich (2002) and Sousa (2007).

2 In the work of Sousa (2008), the impact of comprehensive income on ROE for the ensemble of a sample of companies listed on the Madrid Stock Exchange and by sectors is analysed, but only for the years 2004-2006. This means the effect of the current serious crisis is not assessed in this ratio, particularly for 2008. Moreover, all the companies listed on the Madrid Stock Exchange are taken in the sample for the study, whereas in our paper we take as reference those listed on the IBEX-35, the benchmark index for the Madrid Stock Exchange as it comprises the 35 most liquid companies of said market.

3 We have reached these results by taking shareholders equity values as of the closure of the financial year for each of the years studied. As was stated, there was no information available to calculate the average values for 2004, and in order to not exclude this year it was decided to use the closing values instead of the average values for all the period. In any case, the results of the statistical contrasts, and therefore of our research, are practically the same regardless of the values considered, that is, average values or values taken at the end of the financial year. 


\section{NOTES}

